\title{
Erratum to: Wnt6 is required for maxillary palp formation in Drosophila
}

\author{
Nikolaos Doumpas ${ }^{1}$, Gáspár Jékely ${ }^{2}$ and Aurelio A. Teleman ${ }^{1 *}$
}

\section{Correction}

We realized that our 2013 publication describing Wnt6 knockout flies [1] contains a presentation error which does not impact any of the data or conclusions of the manuscript.

Figure 1a, illustrating the genomic region that was knocked-out in the Wnt6 [KO] flies, is not correct. The knockout takes out exon 1, not exon 3 . Hence the gray shading in Figure 1a is in the wrong spot, and the corresponding text in the Results section is not correct. The actual knockout allele removes exon 1 of Wnt6, and its translation start site, also leading to complete loss of function. This happened because we originally had two different knockout strategies - one to take out exon 1 , which was successful, and one to take out exon 3, which did not yield knockout animals - and this got mixed up when writing the paper. In the Supplemental Materials of the paper we provided oligo sequences describing the generation of the knockout vector, and those are correct.

We believe this does not impact the results or interpretation of the data. Both of the knockout strategies were designed to yield null alleles. We checked by Q-RT-PCR that no Wnt6 transcript is detectable in the knockout flies (Figure S1B-D') of the paper. The phenotypes described in the paper were rescued with a UAS-Wnt6 transgene, showing they are specific.

Nonetheless, the molecular description of the allele is incorrect, and this can cause confusion when molecularly genotyping the mutant flies, hence we felt it necessary to publish this Correction.

\footnotetext{
* Correspondence: a.teleman@dkfz.de

${ }^{1}$ German Cancer Research Center (DKFZ), Heidelberg, Germany
}

Author details

${ }^{1}$ German Cancer Research Center (DKFZ), Heidelberg, Germany. ${ }^{2}$ Max Planck Institute for Developmental Biology, Spemannstrasse 35, 72076 Tuebingen, Germany.

Received: 2 November 2015 Accepted: 2 November 2015 Published online: 25 November 2015

\section{Reference}

1. Doumpas N, Jekely G, Teleman AA. Wnt6 is required for maxillary palp formation in Drosophila. BMC biology. 2013;11:104.

\section{Submit your next manuscript to BioMed Central and take full advantage of:}

- Convenient online submission

- Thorough peer review

- No space constraints or color figure charges

- Immediate publication on acceptance

- Inclusion in PubMed, CAS, Scopus and Google Scholar

- Research which is freely available for redistribution

Submit your manuscript at www.biomedcentral.com/submit
Ciomed Central

\section{Biomed Central}

(c) 2015 Doumpas et al. Open Access This article is distributed under the terms of the Creative Commons Attribution 4.0 International License (http://creativecommons.org/licenses/by/4.0/), which permits unrestricted use, distribution, and reproduction in any medium, provided you give appropriate credit to the original author(s) and the source, provide a link to the Creative Commons license, and indicate if changes were made. The Creative Commons Public Domain Dedication waiver (http://creativecommons.org/publicdomain/zero/1.0/) applies to the data made available in this article, unless otherwise stated. 